\title{
Silver as a value keeper and wealth distributor during an economic recession
}

\author{
Zuzana ROWLAND ${ }^{1 *}$, Andrea BLÁHOVÁ ${ }^{2}$ and Peng GAO
}

Authors' affiliations and addresses:

${ }^{1}$ Institute of Technology and Business in České

Budějovice, Research department of economics and natural resources management, Okružní

517/10, 37001 České Budějovice, Czech

Republic

e-mail: rowland@mail.vstecb.cz

${ }^{2}$ Institute of Technology and Business in České Budějovice, Research department of economics and natural resources management, Okružní 517/10, 37001 České Budějovice, Czech Republic

e-mail:27089@mail.vstecb.cz

${ }^{3}$ Chongqing University of Technology, Department of Accounting, Hongguang Street, Banan District, 400054 Chongqing, P. R. China e-mail: gaopeng@cqut.edu.cn

\section{*Correspondence:}

Zuzana Rowland, Institute of Technology and Business in České Budějovice, Research department of economics and natural resources management, Okružní 517/10, 37001 České Budějovice, Czech Republic

tel.: +420725007337

e-mail: rowland@mail.vstecb.cz

\section{Funding information:}

Institute of Technology and Business in Ceske Budejovice, 1UZO/05IRP2102

\section{How to cite this article:}

Rowland, Z., Bláhová, A. and Gao, P. (2021). Silver as a value keeper and wealth distributor during an economic recession. Acta Montanistica Slovaca, Volume 26 (4), 796-809.

DOI:

https://doi.org/10.46544/AMS.v26i4.16

\begin{abstract}
The article aims at evaluating the price development of silver from 2011 to 2021, making a safe prediction of its trend to 2022. The experimental evaluation thereby compared economic growth and economic decline. To fulfil the objective, the presented study involved content analysis and smoothing the time series using multilayer perceptron neural networks. The results show that silver is able to keep its value not only in times when investors cease to rely on money but are also impactful for accumulating the wealth of individuals and legal entities. The research revealed that investors should purchase silver within the first two months of 2022, with the expectation of a double return of their deposit until the end of 2022. This will be achieved unless an increase in transaction costs takes place. The achievement is also conditioned by continued government actions of countries in the event of the COVID-19 pandemic.
\end{abstract}

\section{Keywords}

Price of silver, value keeper, wealth, neural networks 


\section{Introduction}

Commodity investment presents an interesting possibility of raising asset value. It concerns an extremely difficult task due to global climatic changes, geopolitical tensions and turbulent economic factors all over the world. Future prices of specific commodities show a high degree of volatility (Ghosh, Sanyal, Jana, 2020) and investing in silver has great investment potential. The problem is that most retail investors prioritize gold over silver, as there is only little known about its great utility, reaching far beyond investment purposes (Novotný, Kruml, 2016). Due to its properties, gold is often in the interest of scientists dealing with the prediction of the development of its value using various predictive methods. Vochozka (2017) used linear regression and artificial neural networks to predict the evolution of gold value.

Silver has also found a practical application in jewellery. Production cost management involves a key factor in increasing the competitiveness of the industry. Precious metals and gems constitute $65 \%$ of jewellery costs (Phitthayanon, Rungreunganun, 2019).

The precious commodity is also widely used in the electronic industry. Extracting silver from available resources, namely e-scraps, grows in importance thanks to a burgeoning demand for electronic industry and underlying issues with E-scraps disposal (Yoo, So, Yang, Lee, 2019).

Specific materials, including silver and its alloys, can stimulate heightened antimicrobial activity. The complex problem of applying silver on materials that come into contact with food lies in the lack of knowledge of making ingredients, stability of serving systems in food-processing matrices and health risks caused by such properties that, at the same time, offer convenience (Yoo, So, Yang, Lee, 2015).

The price constitutes another crucial aspect (Vrchota, Březinová, 2014; Škapa, Vochozka, 2020). There is always a way how to predict the development of commodity prices (Vochozka, Vrbka, Suler, 2020). Those who want to foresee the trend in prices of gold and silver use bagging trees and random forests as an unbeatable combination of accuracy and realistic estimate. All portfolios of gold and silver involving prognoses of trends in random forest prices surpassed the portfolio of purchase and possession (Sadorsky, 2021). Commodity market prices can be simulated by various models (Březinová, Vrchota, 2015). The global supply from mining, exhaustion of remaining resources, decrease in ore quality, market prices and the turnover of silver was simulated using SILVER Model developed for the presented study. The model combines the mining process, business markets, price mechanisms, population dynamics, its use in the society and waste and recycling into the integrated system (Sverdrup, Koca, Ragnarsdottir, 2014).

The article aims at evaluating the development of the price of silver from 2011 to 2012, making a reliable prediction until 2022. The research thereby builds on the evaluation of the up-to-now development of prices of silver from 2011. The experimental period starts in times of the global economic crisis that began in 2008. The era continues with spectacular economic growth until the COVID-19 pandemic. The times of the pandemic witnessed enormous government expenditure to compensate for damage caused by COVID-19 (Dias et al., 2020). The research question RQ1 is thereby formulated as follows:

What was the development of the price of silver from 2011 to 2021 ?

The critical evaluation will give grounds to modelling a trend of the price of silver during an economic decline and economic growth. The acquired findings will allow us to answer RQ2:

What will be the price of silver throughout 2022 ?

\section{Literary Review}

A number of authors point out data preparation for successful analysis (Stehel, Vochozka, 2016). The meaning and the potential use should be transferred into the model construction (Brezinová, Průšová, 2014). Sadorsky (2021) uses several classifiers of tree machine learning (bagging, increasing Stochastic gradient, random forests) to predict trends of price funds negotiated on the stock market with gold and silver. Those who want to forecast the trend in prices of gold and silver use bagging trees and random forests as an unbeatable combination of accuracy and realistic estimate.

Yaya, Xuan Vinh Vo, Olayinka (2021) designed deep learning models, predicting prices of raw materials used in jewellery - silver, gold and diamond. These models are constructed for small-sized Thai jewellery producers. Our imitations take into account only historical price figures (Phitthayanon, Rungreunganun, 2019). The fact that cointegration exists in prices and resources of gold and silver implies that prices of gold and silver and stock may be interchangeably used for breaking into the commodity market, supposing that these two commodities are not negotiated within the same portfolio.

Numerical studies have employed the suggested method to analyze the sensitivity of time series of oil and gold. FSA results reveal that the oil price strongly depends on the inflation rate, dollar index and market index, whereas OPEC production rate and price of gold are only slightly influential. Modelling the price of gold shows the strongest sensitivity in the price of silver, while the demand for gold is derived from the market index and inflation rate (Lotfi, Babrzadeh, Khosravi, 2020; Škapa, Vochozka, 2019). 
The study focuses on making short-time predictions of diseases' epidemiology, which could be instrumental for policymakers and public institutions to take crucial short-term decisions. We use comprehensive data on spreading COVID-19 in Lithuania to evaluate the effectiveness of the adopted method based on combining specific algorithms, data mining and classic ARIMA model for making short-term predictions. We further analyzed prognoses of the epidemic dynamics and involved the results in the study. The submitted research might as well be applicable to any other country during any pandemic (Markeviciute, Bernataviciene, Levuliene, Medvedev, Treigys, Venskus, 2022). The presented article deals with short-term data predictions on a new coronavirus (COVID-19) for the infected, recurrent and active cases using Gauss and ARIMA machine-learned hybrid method for the virus-spreading in India. Several parameters were subject to tests of the relevance of individual evaluation of prognostic methods. The results, however, show that ARIMA $(2,1,0)$ makes better predictions for the data system (Bhardwaj, Alowaidi, Bhardwaj, Sharma, 2021).

The conducted content analysis focuses on identifying generative relationships in the learning area, sorting out the content so that the generative learning enjoys the maximum support (Wojtyra et al., 2020). The inquiry suggests that the content analysis gives grounds to generative learning for learning program designers to create more effective and efficient software if they were more involved in content analysis (Slocum, Rolf, 2021).

Nouri (2022) discusses different factors involved in the synthesis of nanoparticles containing a contrast agent, with a demonstration of the essential ones. Nouri (2022) focused on the research theory, exploring the methodology of content analysis by looking up keywords related to nanotechnology, molecular representation, methods of medication delivery, gene therapy, nanoparticles containing a contrast agent on Google websites, PubMed, Science Direct, Scholar and Scopus. Upon achieving a substantial number of articles, he selected ten studies, which constitute this article.

Lacy, Watson, Riffe, Lovejoy (2015) explore three common pitfalls of content analysis, concluding with a list of established techniques of content analysis. The part Established Techniques includes forward steps to retrieve reliable and valid data acquired from the content analysis, containing adequate records of these steps to allow thorough evaluation.

Wang and Ji (2015) suggest a general framework for analyzing emotional video content, exploring the relations between the video content, emotional descriptors and spontaneous non-verbal responses of users. Subsequently, the authors carried out a study on the current research regarding direct and implied analysis of the emotional video content focused on the direct analysis of the emotional content of the video. The authors conclude by identifying several weaknesses of the research, proposing corrections for these deficiencies.

The visual content analysis and examination of photographic data from the scene and content analysis and perceptual mapping revealed differences between the perceived and projected online DI of east Taiwan. The aforementioned tests disclosed that TGC and NTO content provided a similar representation of east Taiwan, as the destination is endowed with "natural environment", "infrastructure", "various leisure-time activities", and "major tourist attractions" (Mak, 2017).

The F-s time series analysis allowed the identification of F-s periodic formulae that are strongly dependent on periods of humidity and temperature. Humidity was a decisive F-s factor in weekly and monthly time intervals, whereas temperature dominated in daily time spans. Humidity was more impactful on F-s in lichens and soil under grass, while temperature radically affected F-s in blue-green algae and bare soil (Chamizo, Rodriguez-Caballero, Sanchez-Canete, Domingo, Canton, 2022).

The article intends to compare the method of exponential smoothing and smoothing by artificial neural networks as a means of foreseeing the development of stock prices, giving Unipetrol company as an example. A more realistic image of a possible future development was surprisingly conjured up by the exponential smoothing method (Horák, Krulický, 2019). Regarding the generation of a highly complex and vast mass of data, the time series must handle, constructing prediction models for these data poses huge challenges. This article seeks a full description of methods of modelling time series, including their detailed classification. We also compare different methods, suggesting potential techniques to predict trends in the time series development (Liu, Zhu, Gao, Xu, 2021).

This article discusses a method of multidimensional prediction, comparing the prediction effectiveness of multidimensional time series with one-dimensional time series and non-parametric regressive model of K Nearest Neighbour (KNN). It turns out that the suggested method of the multidimensional prediction outplays the method of one-direction forecast and the KNN method in foreseeing time series (Yin, Shang, 2016). The article further suggests that digital media pose such a radical challenge to the analysis of the media content that established techniques provide rather subpar results, which only reflects basic requirements inherited from analogue media formats. The article concludes that traditional content analysis cannot keep up with digital media development. However, the new alternative approaches to tackling digital journalism have yet to be standardized, protocolized and unified (Karlsson, Sjovaag, 2016).

Vochozka, Horák and Šuleř (2019) devised a methodology for assessing seasonal variations in smoothing the time series through artificial neural networks, giving Euro and Chinese Yuan as examples. Before the beginning, the experiment did not seem to require involving categoric variables in the calculation; still, the results showed 
that other variables, including the year, month, the day of the month and the weekday of measuring, brought higher accuracy and the correct order in smoothing time series (Vochozka, Horák and Suler, 2019). Vrbka et al. (2019) used artificial neural networks to predict the balance of payments between the United States and the People's Republic of China. This is another publication dealing with the prediction of values depending on seasonal fluctuations. Machová, Vochozka, Horák (2019) presented very potential results of artificial neural networks.

Yet, we cannot heavily rely on the predicted data, as it may lead to substantial losses in the event of software failure. Vochozka, Horák and Krulický (2020) work toward innovating the forecast management to foresee the intime development of stock prices using neural networks. MLP networks deliver higher stable performance than SVR and BPNN networks in all data sets. The final evaluation shows a standard deviation of $2.26 \%$, occurring in the most significant difference within the maximum and minimum prediction (Vochozka, Horák and Krulický, 2020).

Autoregressive integrated moving average (ARIMA) presents a good, flexible and easily applicable linear model in univariate analysis of time series prognosis. Suhermi, Suhartono, Prastyo and Ali (2018) adapt the hybrid methodology to combine ARIMA, deep neural network model (DNN) and ANN model with several hidden layers.

Saleh Ahmar, Kumar Singh, Van Thanh, Viet Tinh and Vo Minh Hieu (2022) suggest two different models to detect the trend in stock prices in Brazil (BVSP), Russia (IMOEX.ME), India (BSESN) and China (SSE), i.e. (BRIC). The authors (2022) predict the stock prices for three-day periods so that potential problems may be adequately tackled. First, the authors (2022) compared ARIMA, SutteARIMA and Holt-Winters (H-W) methods to determine the most effective prediction model. Model Holt-Winters appeared to be the most efficient to foresee stock prices in Brazil (BVSP), while MAPE (0.50) and MSE (579272.65), Holt-Winters (lower than ARIMA and SutteARIMA) and model SutteARIMA was instrumental in forecasting stock prices in Russia (IMOEX.ME), India (BSESN) and China (SSE) compared to ARIMA and Holt-Winters. Groda and Vrbka (2017) used the ARIMA model to predict the development of stock prices on the Prague Stock Exchange, as the development of stock prices is non-linear. In conclusion, however, they state that the ARIMA model achieves only low predictive accuracy when used for this purpose.

The study aimed at applying Alpha-Sutte Indicator and ARIMA for a general data prediction. Alpha-Sutte Indicator constitutes a new method of forecasting developed by Ansari Saleh Ahmar Company in 2017. The prognosis results revealed that Alpha-Sutte Indicator holds MSE and MAE values that are lower than in other methods (ARIMA) (Sutiksno, Ahmar, Kurniasih, Susanto, Liewakabessy, 2018). Autoregressive integrated moving average (ARIMA) presents a convenient method of predicting time series data with high accuracy, as shown in previous studies (Dhini, Surjandari, Riefqi, Puspasari, 2015).

Yildiran, Fettahoglu (2017) predict USDTRY rates of exchange using the ARIMA method, having conducted 3,069 daily observations between 3rd January 2005 and 8th March 2017, with the production of long-term and short-term models. The authors (2017) employ the generation of a dynamic model, making multi-step predictions during observations carried out outside the experimental sample. The authors combined the ARIMA model with BP neural network to preserve the prediction accuracy. First, they constructed the ARIMA prognostic model followed by the production of a BP neural network to support the single former model. The rest of the ARIMA model is trained and equipped with BP neural network. Its right combination with outcomes provided by the ARIMA model yields more accurate results. The practise shows that a new ARIMA model upgraded by BP neural networks makes more accurate predictions, compared to a single ARIMA model, while the standard deviation of the forecast significantly plummeted by $10.4 \%$ (Ji, Yu, Guo, Zhang, 2016).

In the event of Mobile Edge, reliable prediction of the quality of service (QoS) is imperative in providing web services. By integrating packed matrices extracted from QoS matrices via abridged Singular Value Decomposition (SVD) into the classic ARIMA model, Yan, Zhang, Zhong, Zhang, Xin (2022) work toward developing an ARIMA model to forecast multiple QoS values effectively and at a time. Experimental results demonstrate that our approach eclipses other utmost modern techniques in terms of accuracy and effectiveness.

The method of multilayer perceptron neural networks of radial basis function network proved to be the most efficient technique.

\section{Materials and Methods}

The data for the analysis are available on the websites of the World Bank. The study involves information on rates of exchange of the price of one ounce of silver on Kurzy.cz. The interval within which the data will be available refers to the final value of an ounce of silver beginning on 24. 10. 2011 and ending on 29.10.2021. Diagram 1 suggests the development of the price of silver.

At the beginning of October 2011, the price of silver amounted to 32 USD, followed by a sharp decline. Subsequently, the price of this commodity soared to the highest value of the whole period amounting to 37 USD. On 24.10. the price dropped to 35 USD. October 2013 saw a price slump to 18.45 USD, and until 2019 the price oscillated between 18 and 20 USD. Silver again witnessed a downward slide in its price to 12.06 USD on 19.3.2020. In August 2020, the price rose again to 28.91 USD with a sudden downturn to 23 USD on 29.10. 
Diagram 1 The development of the price of silver from 24. 10. 2011 to 29. 10. 2021

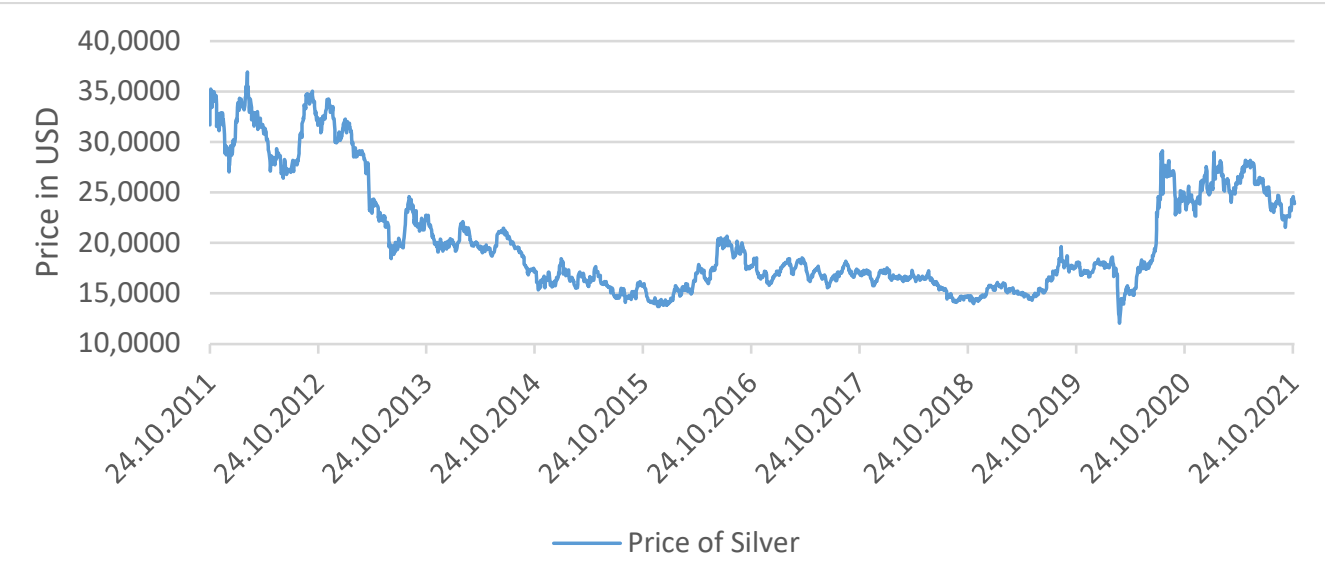

Source: Kurzy.cz [online]. [cit. 2021-11-13]. Available on: https://www.kurzy.cz/komodity/stribro-graf-vyvojeceny/

We apply neural structure regression of Statistica Software from TIBCO Company, version 13.0. The precise calculation involves multilayer perceptron networks ("MLP") and neural networks of the basic radial function ("RBF"), including the price of silver as a dependent variable. MLP works with time units as an independent variable (date, year, month, month day, weekday) to monitor all potential seasonal variations. RBF was assigned a specific date as an independent variable. Vochozka, Rowland, Šuleř and Maroušek (2020) provided our research only with time series from 30.10.2019 to 29.10.2021.

We randomly divide the time series of both types of neural networks into three data sets - train, test and validation. The first group involves $70 \%$ of the input data, allowing us to generate neural structures. The two remaining data sets are left with $15 \%$ of the input data. Both groups help us assess the reliability of the detected neural structure. Table 1 suggests acquired data.

Table 1 depicts the statistical characteristics of the data set.

Table 1 Statistical characteristics of the data set

\begin{tabular}{|l|r|r|}
\hline \multicolumn{1}{|c|}{ Samples } & \multicolumn{1}{c|}{ Date } & $\begin{array}{c}\text { Silver Price in } \\
\text { USD }\end{array}$ \\
\hline Minimum (Train) & 43768.00 & 12.05 \\
\hline Maximum (Train) & 44498.00 & 29.02 \\
\hline Mean (Train) & 44137.70 & 22.44 \\
\hline Standard deviation (Train) & 208.29 & 4.37 \\
\hline Minimum (Test) & 43776.00 & 14.71 \\
\hline Maximum (Test) & 44489.00 & 29.12 \\
\hline Mean (Test) & 44105.32 & 21.65 \\
\hline Standard deviation (Test) & 231.54 & 4.28 \\
\hline Minimum (Validation) & 43777.00 & 14.33 \\
\hline Maximum (Validation) & 44488.00 & 28.23 \\
\hline Mean (Validation) & 44151.17 & 22.66 \\
\hline Standard deviation (Validation) & 332.45 & 5.20 \\
\hline Minimum (Overall) & 43768.00 & 12.05 \\
\hline Maximum (Overall) & 44498.00 & 29.12 \\
\hline Mean (Overall) & 44134.88 & 22.36 \\
\hline Standard deviation (Overall) & 211.34 & 4.32 \\
\hline
\end{tabular}

Source: author

Minimum (train) and minimum (test) differ by 2.66 USD. Minimum (validation) has a value by 2.28 USD higher than the minimum (overall). The difference between values of maximum (train) and maximum (test) amounts to -0.01 USD. Maximum (validation) is lower by 0.89 USD than maximum (overall). The difference of 
values mean (train) and mean (test) is 0.8 USD. Mean Validation is higher by 0.3 USD than mean (overall). The standard deviation (overall) is lower by 0.88 USD than the standard deviation (validation).

We generate 10,000 neural networks in both neural networks. The calculation preserves 5 artificial neural networks with the best characteristics.

We will further be working with 2 to 8 neurons in the hidden layer of MLP. We will thereby consider the following activation functions in the hidden and output layer of the MLP:

- Linear,

- Logistics,

- Atanh,

- Exponential,

- Sinus.

We examine 21 - 30 neurons in the hidden layer of RBF.

The other settings will remain default (according to ANN - automated neural networks). If necessary, we will generate weight values per iteration of individual neurons using ONN tools (own neural networks). We have to say, though, that the improvement using ANN is rather random than the results of a complex procedure with an easily calculable outcome.

The result will thereby provide us with an answer to Hypothesis 1 - the model of the price behaviour of silver.

The achieved neural networks will be saved in PMML format after we have chosen a neural structure with the best prerequisite to predict the future price development of silver until the end of 2022 . To forecast the price development of this commodity until the end of 2022, we import neural networks back to Statistica Software, assigning trading days and calculating future values of silver until 31.12.2022. In this way, we receive an answer to Hypothesis 2.

\section{Results}

\section{Analysis of the up-to-now price development of silver}

Smoothed time series of the price of silver are presented according to the type of the used neural network.

\section{Multilayer perceptron networks}

Table 2 provides an overview of the retained MLP networks, indicating the 5 best structures generated for the price of silver. The first column contains the following numbers: 5 date, year, month, month day and weekday; 6 11 number of neurons in the hidden layer - revealed through the experiment, 1 price of silver. The third, fourth and fifth column involves the performance of individual retained structures, which roughly amounts to $98 \%$ in all cases. The sixth, seventh and eighth column shows train, test and validation network errors. The errors occur within the range of 0.2 to 0.29 , which indicates low error rates. The next column includes the training algorithm BFGS (Broyden-Fletcher-Goldfarb-Shanno algorithm), with each network tested on a different type. The column Error function worked on SOS (square sum) method. The last but one column indicates two applicable functions logistic and logistic tangents. The output activation layer involves the following functions: identity, tangents, logistic and sine.

Table 2 Overview of retained MLP networks

\begin{tabular}{|r|c|r|r|r|r|r|r|r|r|r|r|}
\hline Index & Net. name & $\begin{array}{c}\text { Training } \\
\text { perf. }\end{array}$ & $\begin{array}{c}\text { Test } \\
\text { perf. }\end{array}$ & $\begin{array}{c}\text { Validation } \\
\text { perf. }\end{array}$ & $\begin{array}{c}\text { Training } \\
\text { error }\end{array}$ & $\begin{array}{c}\text { Test } \\
\text { error }\end{array}$ & $\begin{array}{c}\text { Validation } \\
\text { error }\end{array}$ & $\begin{array}{c}\text { Training } \\
\text { algorithm }\end{array}$ & $\begin{array}{c}\text { Error } \\
\text { function }\end{array}$ & $\begin{array}{c}\text { Hidden } \\
\text { activation }\end{array}$ & $\begin{array}{c}\text { Output } \\
\text { activation }\end{array}$ \\
\hline 1 & MLP 5-6-1 & 0.99 & 0.99 & 0.99 & 0.24 & 0.29 & 0.26 & BFGS 274 & SOS & Logistic & Identity \\
\hline 2 & MLP 5-10-1 & 0.99 & 0.99 & 0.99 & 0.21 & 0.25 & 0.26 & BFGS 213 & SOS & Tanh & Tanh \\
\hline 3 & MLP 5-10-1 & 0.99 & 0.99 & 0.98 & 0.22 & 0.24 & 0.27 & BFGS 152 & SOS & Tanh & Logistic \\
\hline 4 & MLP 5-11-1 & 0.99 & 0.99 & 0.98 & 0.21 & 0.24 & 0.27 & BFGS 187 & SOS & Tanh & Exponential \\
\hline 5 & MLP 5-10-1 & 0.99 & 0.99 & 0.99 & 0.2 & 0.26 & 0.26 & BFGS 229 & SOS & Tanh & Sine \\
\hline
\end{tabular}

Source: author

Table 3 compares predictions characterized by real-time series (the overview in Table 1)

Table 3 MLP prediction statistics

\begin{tabular}{|l|r|r|r|r|r|}
\hline \multicolumn{1}{|c|}{ Statistics } & \multicolumn{1}{c|}{$\begin{array}{c}\text { 1.MLP 5- } \\
\text { 6-1 }\end{array}$} & $\begin{array}{c}\text { 2.MLP 5- } \\
10-1\end{array}$ & $\begin{array}{c}\text { 3.MLP 5- } \\
10-1\end{array}$ & $\begin{array}{c}\text { 4.MLP 5- } \\
11-1\end{array}$ & $\begin{array}{c}\text { 5.MLP 5- } \\
10-1\end{array}$ \\
\hline Minimum prediction (Train) & 13.16 & 13.2 & 14.02 & 14.09 & 13.29 \\
\hline Maximum prediction (Train) & 28.01 & 27.73 & 27.52 & 27.92 & 27.75 \\
\hline Minimum prediction (Test) & 14.43 & 14.18 & 14.35 & 14.44 & 14.41 \\
\hline Maximum prediction (Test) & 27.92 & 27.72 & 27.48 & 27.87 & 27.77 \\
\hline Minimum prediction (Validation) & 13.29 & 13.33 & 14.01 & 14.2 & 13.29 \\
\hline
\end{tabular}




\begin{tabular}{|l|r|r|r|r|r|} 
Maximum prediction (Validation) & 27.74 & 27.5 & 27.47 & 27.9 & 27.66 \\
\hline Minimum residual (Train) & -2.15 & -2.3 & -2.31 & -2.61 & -1.87 \\
\hline Maximum residual (Train) & 2.35 & 2.22 & 2.32 & 2.04 & 1.93 \\
\hline Minimum residual (Test) & -2.11 & -2.28 & -2.49 & -2.07 & -2.24 \\
\hline Maximum residual (Test) & 2.13 & 1.73 & 1.77 & 1.61 & 1.96 \\
\hline Minimum residual (Validation) & -2.27 & -2.66 & -2.57 & -2.74 & -2.72 \\
\hline Maximum residual (Validation) & 1.46 & 1.57 & 1.63 & 1.64 & 1.54 \\
\hline Minimum standard residual (Train) & -4.4 & -5.01 & -4.9 & -5.64 & -4.16 \\
\hline Maximum standard residual (Train) & 4.82 & 4.84 & 4.93 & 4.4 & 4.3 \\
\hline Minimum standard residual (Test) & -3.94 & -4.58 & -5.09 & -4.22 & -4.42 \\
\hline Maximum standard residual (Test) & 3.99 & 3.47 & 3.61 & 3.3 & 3.88 \\
\hline Minimum standard residual (Validation) & -4.49 & -5.21 & -4.9 & -5.3 & -5.33 \\
\hline Maximum standard residual (Validation) & 2,88 & 3,08 & 3,12 & 3,18 & 3,01 \\
\hline
\end{tabular}

Source: author

The minimum prediction (train) is higher in all networks as the minimum (train) amounts to 12.05 USD. Maximum prediction (train) has lower values in all networks. The actual price of silver in maximum (train) equals 29.02 USD. Minimum prediction (test) indicates roughly 14 in all networks. The actual value of the minimum (test) is 14.71 USD. All the networks thereby indicate minimal deviations. The maximum prediction (test) value is about 27 in all networks, whereas the actual maximum (test) reaches 29.12 USD. The minimum prediction (validation) ranges from 13 to 14 in all networks. The minimum (validation) value equals 14.33 USD, while the maximum prediction (validation) roughly amounts to 27 . The maximum (validation) value is 28.23 USD.

Diagram 2 depicts an actual development of the examined time series in a blue line.

Diagram 2 Smoothed time series using MLP

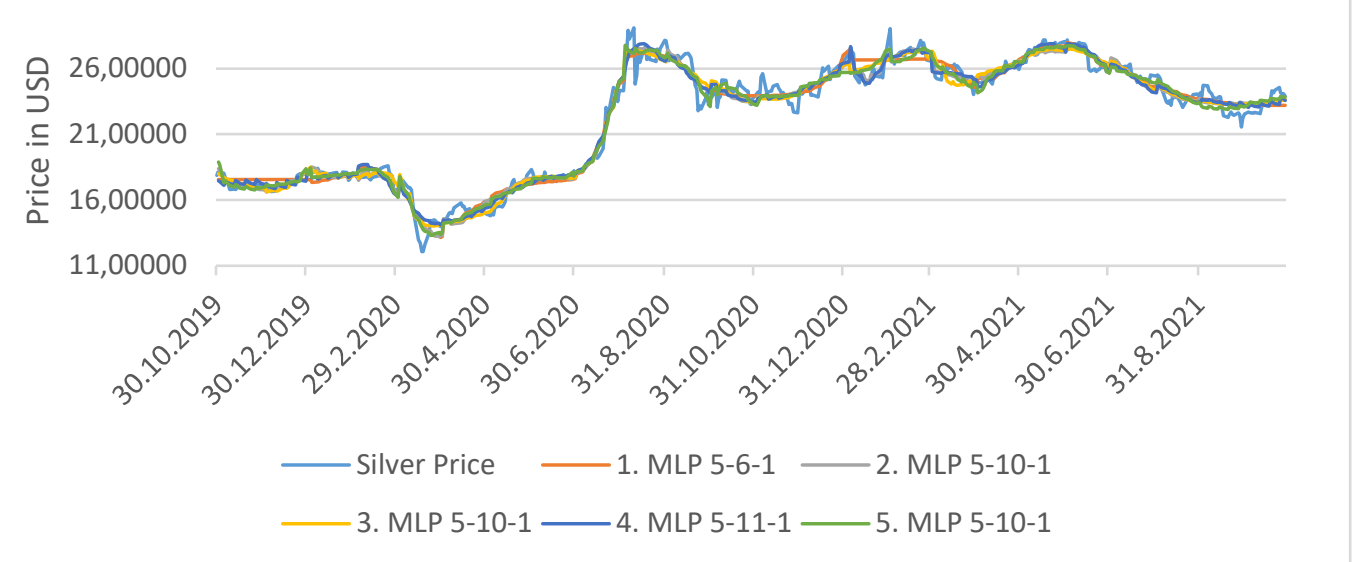

Source: author

Other neural networks fall into MLP time series. In the period from 30.10.2019 to 29.2.2020, the curves overlap to some extent, which indicates the good functionality of the model. We can see the first difference on 18.3.2020, continuing through 9.4.2020, when the price amounts to 15.4 USD. The actual price soars to 29.12 USD on 10.8.2020, showing a substantial deviation from other networks. We witness another significant disparity on 1.2.2021, where the price equals 29.02 USD. The price plummeted to 21.53 USD on 29.9.2021, again reflecting a dramatic difference from other networks.

\section{Radial Basic Function Neural Networks - RBF}

Table 4 suggest an overview of retained RBF

Table 4 an overview of retained RBF

\begin{tabular}{|c|c|c|c|c|c|c|c|c|c|c|c|}
\hline $\begin{array}{c}\text { Inde } \\
x\end{array}$ & Net. name & $\begin{array}{c}\text { Training } \\
\text { perf. }\end{array}$ & $\begin{array}{l}\text { Test } \\
\text { perf. }\end{array}$ & $\begin{array}{l}\text { Validation } \\
\text { perf. }\end{array}$ & $\begin{array}{c}\text { Training } \\
\text { error }\end{array}$ & $\begin{array}{l}\text { Test } \\
\text { error }\end{array}$ & $\begin{array}{c}\text { Validation } \\
\text { error }\end{array}$ & $\begin{array}{l}\text { Training } \\
\text { algorithm }\end{array}$ & $\begin{array}{c}\text { Error } \\
\text { function }\end{array}$ & $\begin{array}{c}\text { Hidden } \\
\text { activation }\end{array}$ & $\begin{array}{c}\text { Output } \\
\text { activation }\end{array}$ \\
\hline 1 & RBF 1-28-1 & 0.98 & 0.98 & 0.99 & 0.3 & 0.34 & 0.25 & RBFT & SOS & Gaussian & Identity \\
\hline 2 & RBF 1-29-1 & 0.99 & 0.98 & 0.99 & 0.27 & 0.34 & 0.22 & RBFT & SOS & Gaussian & Identity \\
\hline 3 & RBF 1-26-1 & 0.99 & 0.98 & 0.98 & 0.28 & 0.37 & 0.27 & RBFT & SOS & Gaussian & Identity \\
\hline 4 & RBF 1-21-1 & 0.99 & 0.98 & 0.98 & 0.23 & 0.3 & 0.26 & RBFT & SOS & Gaussian & Identity \\
\hline 5 & RBF 1-29-1 & 0.98 & 0.98 & 0.99 & 0.31 & 0.33 & 0.25 & RBFT & SOS & Gaussian & Identity \\
\hline
\end{tabular}


Source: author

Table 5 proposes the five best neural structures generated for the price of silver. The first column deals with the following numbers: 1, 21-29 neurons in the hidden layer - revealed by the experiment., 1 price of silver. The third, fourth and fifth columns show individual retained structures' performance. All networks perform at 97-98\%. All the structures are thereby highly efficient. The sixth, seventh and eighth column involves train, test and validation network errors, ranging between 0.22 and 0.37 . The next column illustrates a training algorithm where we used the RBFT algorithm. The column Error function uses SOS (square sum) method. The last but one column includes the Gauss function, and the output activation layer suggests the Identity function.

The basic statistics of the train, test and validation data set in all five retained models are compiled in Table 5.

Table 5 RBF prediction statistics

\begin{tabular}{|c|c|c|c|c|c|}
\hline Statistics & $\begin{array}{c}\text { 1. RBF 1- } \\
28-1\end{array}$ & $\begin{array}{l}\text { 2.RBF 1- } \\
29-1\end{array}$ & $\begin{array}{c}\text { 3. RBF 1- } \\
26-1\end{array}$ & $\begin{array}{c}\text { 4. RBF 1- } \\
21-1\end{array}$ & $\begin{array}{c}\text { 5.RBF 1- } \\
29-1\end{array}$ \\
\hline Minimum prediction (Train) & 13.99 & 14.21 & 14 & 13.38 & 14.02 \\
\hline Maximum prediction (Train) & 28.91 & 27.95 & 28.05 & 27.86 & 27.69 \\
\hline Minimum prediction (Test) & 14.23 & 14.36 & 14.04 & 14.57 & 14.11 \\
\hline Maximum prediction (Test) & 28.3 & 27.96 & 27.6 & 27.72 & 27.6 \\
\hline Minimum prediction (Validation) & 14.02 & 14.23 & 14.01 & 13.42 & 14.06 \\
\hline Maximum prediction (Validation) & 27.99 & 27.86 & 28.05 & 27.85 & 27.71 \\
\hline Minimum residual (Train) & -2.64 & -2.5 & -2.62 & -1.97 & -2.71 \\
\hline Maximum residual (Train) & 2.22 & 3.3 & 2.75 & 3.16 & 3.2 \\
\hline Minimum residual (Test) & -1.91 & -2.5 & -2.27 & -2.21 & -2.34 \\
\hline Maximum residual (Test) & 2.86 & 2.76 & 2.67 & 2.98 & 1.9 \\
\hline Minimum residual (Validation) & -1.65 & -2.14 & -1.98 & -1.83 & -2.9 \\
\hline Maximum residual (Validation) & 1.61 & 2.09 & 1.922 & 2.28 & 1.168 \\
\hline Minimum standard residual (Train) & -4.83 & -4.82 & -4.93 & -4.16 & -4.86 \\
\hline Maximum standard residual (Train) & 4.08 & 6.35 & 5.195 & 6.66 & 5.74 \\
\hline Minimum standard residual (Test) & -3.3 & -4.27 & -3.74 & -4 & -4.09 \\
\hline Maximum standard residual (Test) & 4.93 & 4.71 & 4.4 & 5.4 & 3.32 \\
\hline Minimum standard residual (Validation) & -3.28 & -4.52 & -3.81 & -3.61 & -5.75 \\
\hline Maximum standard residual (Validation) & 3.2 & 4.42 & 3.7 & 4.5 & 2.32 \\
\hline
\end{tabular}

Source: author

Ideally, the data draw close to the actual values of the time series (see Table 1). However, the residue characteristics should approach zero as much as possible. In such a case, the model would readily detect not only the prevailing global trend (of the time series) but also its local extremes. In this situation, we may thereby argue that extreme residual values are close to zero, indicating quite an efficient and effective model.

Diagram 3 compares the actual price development of silver and smoothed time series using RBF.

Diagram 3 Smoothed time series using RBF

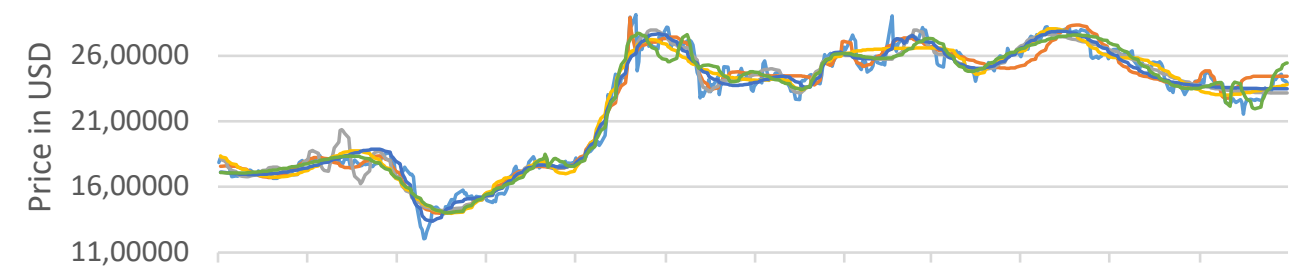

11,00000

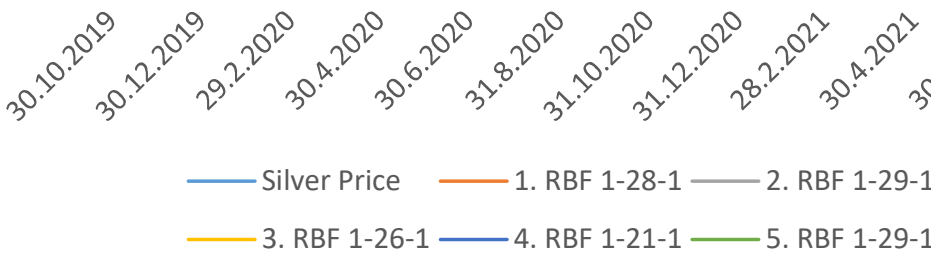

Source: author 
The blue curve illustrates the actual trend of the time series. Ideally, the models would clearly overlap the curve of the actual prices of silver, which is not the case here. For example, all models dramatically deviate from the actual price of the examined commodity on 18.3.2020, when none of the smoothed time series indicates the real value of silver, which is 29.02 USD. We can observe a similar situation on 1.2.2021. What shall not be omitted either is that all models simplify reality to some extent. The likelihood that a model will $100 \%$ overlaps the reality equals zero, even though neural networks clearly outshine their more-traditional counterparts in performing these tasks.

The resulting model

Based upon the residual values, statistical prediction characteristics and underlying logic of future forecast, Model 4. MLP 5-11-1 shows the best traits. Diagram 4 illustrates smoothed time series and residuals.

Diagram 4 Smoothed price of silver using 4. MLP 5-11-1, residuals

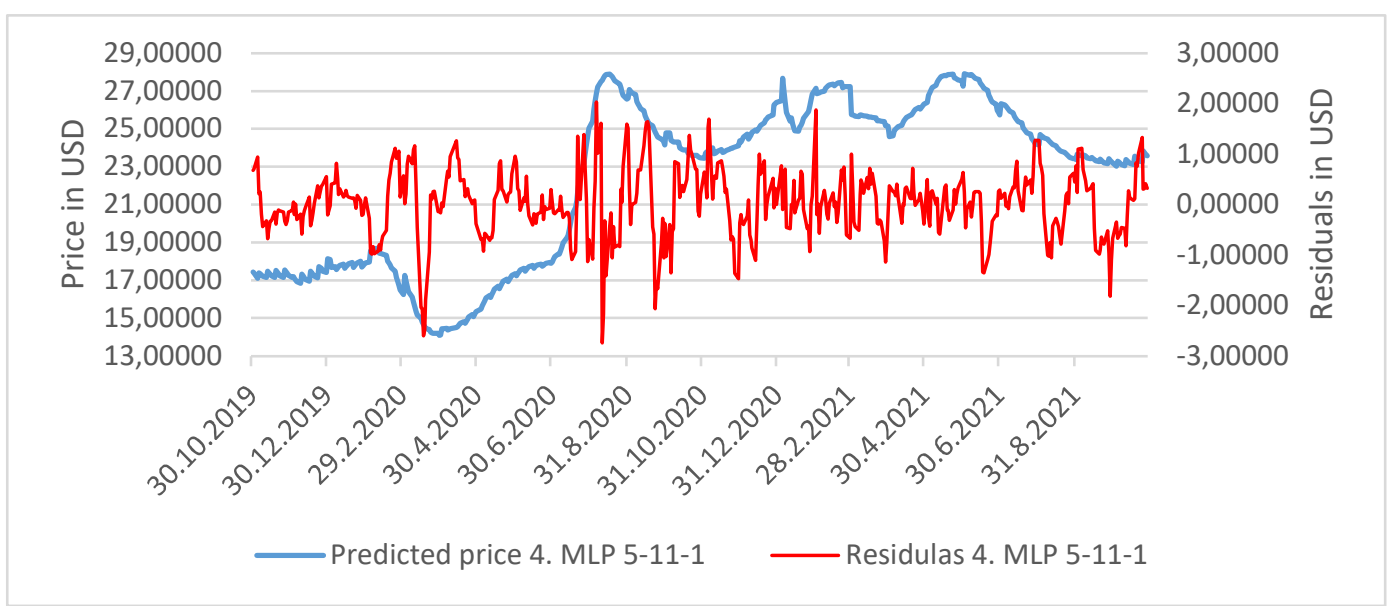

Source: author

The blue line depicts a smoothed time series from 30.10.2019 to 29.10.2021. The model exactly lines the actual development of the price of silver, although we may spot local deviations from the reality. These intermittent aberrations occur in residual values in the monitored period and are illustrated by the second diagram curve. Their maximum values range from a little less than -3 USD to just under 2 USD. Most residuals have values from -1 to 1 USD, though.

Predictions of the price development of silver until the end of 2022

Diagram 5 suggests a prediction of the price development of silver from 1.11.2021 to 31.12.2022.

Diagram 5 prediction of the price development of silver from 1.11.2021 to 31.12.2022.

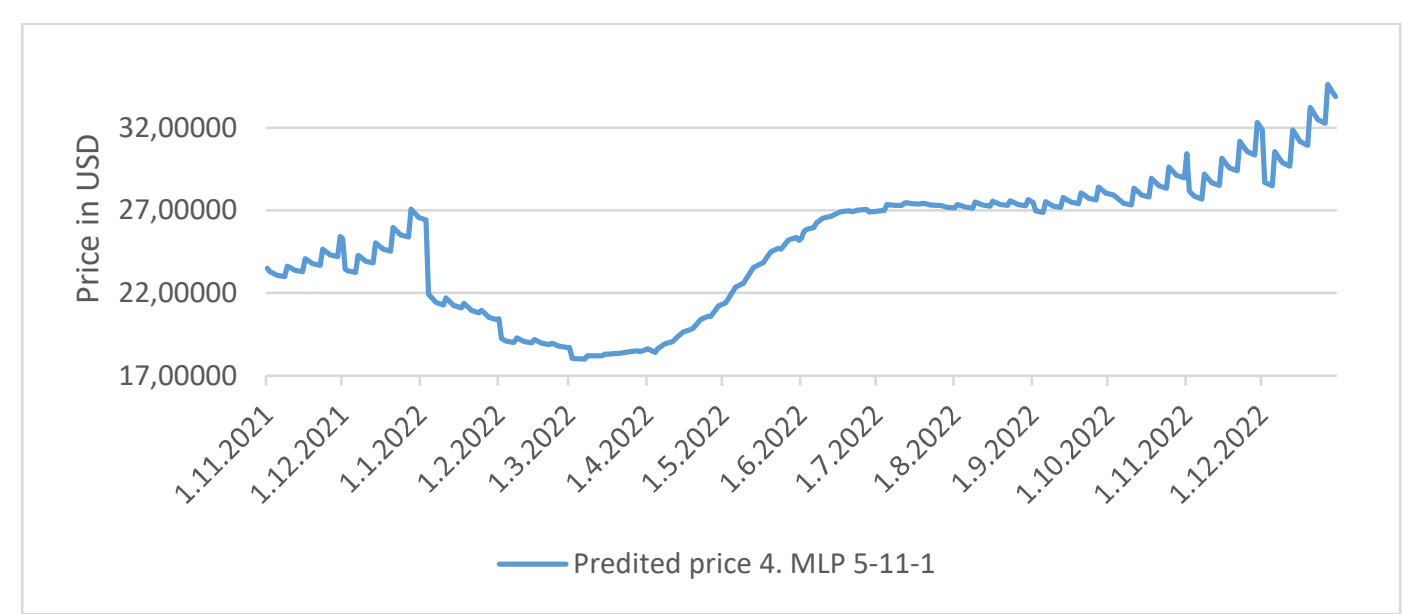

Source: authors. 
The period from 1.11.2021 to 30.12.2021 will witness the price of silver moving between 23-27 USD and plummeting to 21.76 USD on 5.1.2022. The price of the precious commodity will be falling even lower to 18.03 USD at the beginning of March 2022, with a sharp rise to27.34 USD on 5.7.2022. The price of silver will then be settling between 27 and 29 USD until October, with a modest increase to 30.43 USD on 1.11.2022. The price will be topping 34.38 USD on 28.12.2022.

Diagram 6 depicts the price development of silver from 24.10.2011 with a prediction until 31.12.2022.

Diagram 6 The price development of silver from 24.10.2011 until 31.12.2022.

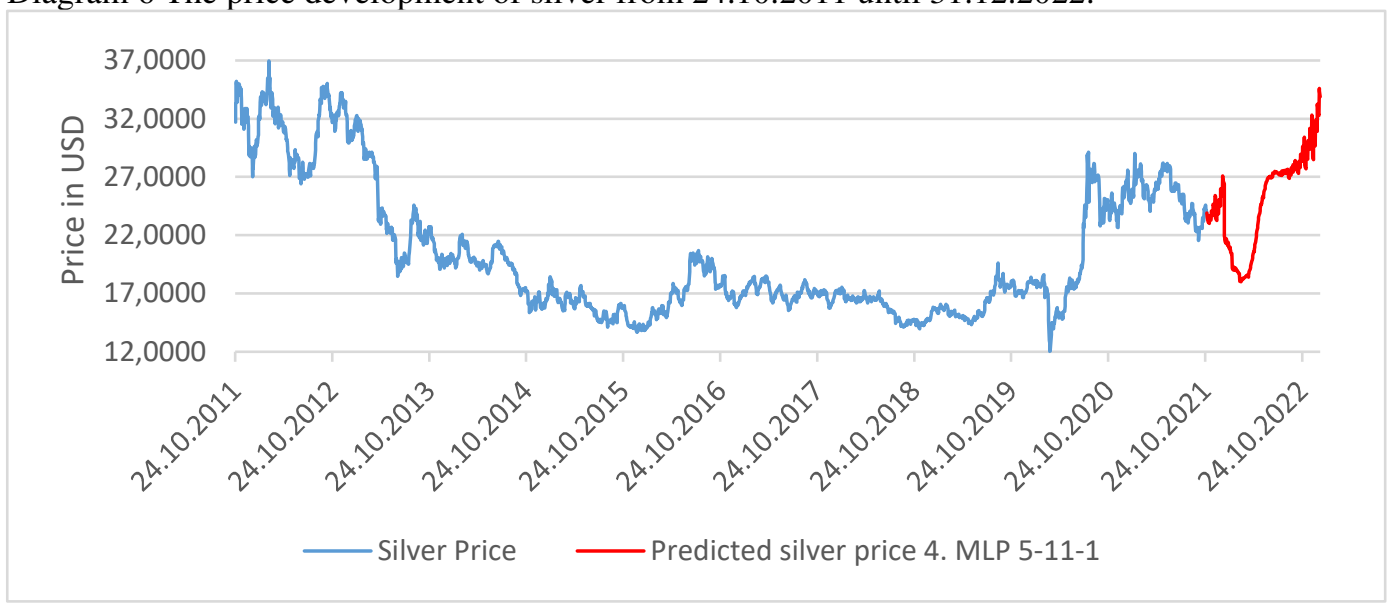

Source: author

The aforementioned diagram gives grounds to answer the second hypothesis on the price development of silver throughout the year 2022. We will be seeing a sheer drop to 18 USD on 7.3.2022, followed by a massive upsurge to 27 USD on 4.7.2022 and steady growth through the rest of the year. We will be witnessing the price peaking at 35 USD in December 2022. During the periods of the price rise of silver, people will be keenly investing in this commodity. The up-to-now trend of the time series leads us to believe in the reliability of the prediction.

\section{Discussion}

The article introduces these research questions:

RQ1: How did the price of silver develop between 2011 and 2021?

The price of silver amounted to 32 USD at the beginning of October 2011, which was followed by a sharp decline in the value of this commodity. The price of silver gradually mounted later in the examined period and eventually peaked at 37 USD. The price equalled 35 USD on 24.10., while October 2013 saw a dramatic fall to 18.45 USD. The price then settled between 18 and 20 USD until 2019. The most significant drop occurred on 19.3.2020, having fallen to 12.06 USD. The price again soared to 28.91 USD in August 2020 and plunged again to 23 USD on 29.10.2021. The price development of silver thereby reflects the economic reality of the global economy, the value of which was high, especially during economic recessions. Nowadays, its price is growing due to the pandemic, when government bodies all around the world impose tough measures against COVID-19. Therefore, we can argue that silver is a reliable value keeper and a much sought-after investment instrument to accumulate wealth when investors and other economic subjects lose trust in money.

\section{RQ2: What will be the price of silver throughout 2022?}

We will be witnessing silver plummet to 18 USD on 7.3.2022 when people are not likely to invest in precious metals due to fuelled mistrust in commodities. It also means that people will be more reliant on money, with no willingness for investments. Many of them will also be looking elsewhere to invest in more attractive commodities. We will be seeing a dramatic rise of the price of silver to 27 USD on 4.7.2022, with a further steady growth through the rest of the year, peaking at 35 USD in December 2022. With the increasing value of silver, people will be willing to invest in this commodity; they will distrust money, targeting steadier profits. The existing time series development proved the prediction correct. With reference to the first hypothesis, we may recommend silver as a negotiable commodity for its steady value. Although the price of silver goes up, its value remains the same, as the value of money drastically declines given the enormous expenses arising from the imposed measures 
during the COVID-19 pandemic. Silver thereby functions as a reliable value keeper. It is, however, more likely that prices are actually growing not only against money (the price rise of silver compensates for people's mistrust in the value of money) but also against other commodities, as silver is a rare precious metal found in natural resources. What to recommend to investors? They will do their best to appreciate their money (keeping its current value) by investing in silver within the first two months of 2022. All the same, we could expect that silver may double its price over time. As has been already mentioned, investors will not only keep its existing value but also substantially increase its value in time.

\section{Conclusion}

The article focused on evaluating the price development of silver from 2011 to 2021, confidently foreseeing its development until 2022. The objective was fulfilled. The price development of silver within 2011 2021 reflects the economic reality of the global economy.

The time-series analysis of the price of silver, although in a short term of 10 years, confirms that the price of the commodity is highly susceptible to the economic cycle of the global economy. The first years of the previous decade saw reverberations of the global economic recession, triggered by the instability of mortgage markets in the USA and lasting several years. At that moment, people turned away from money, looking for more trustworthy value keepers elsewhere. The then price development of silver indicated that the precious metal offered attractive investment opportunities. Its price reached 37 USD per ounce at the beginning of 2012, keeping its value for several months to see it fall heavily to 12 USD per ounce, which means one-third of its value during the recession. The situation is taking a distinctive twist during the COVID-19 pandemic when the price of silver soars up to 30 USD per ounce. People are again turning their backs on money. They expect that introducing draconian measures due to the pandemic will cause an increase in the volume of funds in the volume, affecting all currencies. We can thereby again see intense interest in silver as an investment commodity. However, neural networks predict a sudden downturn of the price of silver to 18 USD per ounce, probably triggered by the optimism bias of investors from developed countries. The citizens of developed countries have fallen for the false information relating to the end of the COVID-19 crisis, selling silver to realize their assets. However, the most recent events have shown that the COVID-19 pandemic is far from being overcome. Although individual countries have adopted a rather moderate attitude towards eliminating the devastating impact of the crisis caused by enormous expenses to suppress the COVID-19 pandemic, potential investors will respond as usual. They will be purchasing real property, artworks and precious metals, including silver. The price of silver will thereby have soared to 35 USD per ounce by the end of 2022. We cannot exactly say to which extent it will preserve the value transferred from money to commodities and to which extent it will increase the financial wealth of its owner. Anyway, today is a very good time to purchase silver as a commodity. The best opportunity to buy this precious metal will come around March 2022 . The bargain is recommended to both - small and large investors.

The foreseen development is expected unless the trading cash for precious metals is restricted. We also need to predict an increase in transaction costs reliably. The last limiting aspect constitutes measures imposed by individual government bodies all over the world. The demand for silver could be seriously affected by government inaction, i.e., the situation when individual government bodies fail to eliminate the impact of the COVID-19 pandemic. In such a case, the investments in silver will be fruitless, with a minimum or no income.

\section{References}

Bhardwaj, S., ALOWAIDI, M., Bhardwaj, R., \& SHARMA, S. K. (2021). Machine learned hybrid Gaussian analysis of COVID-19 pandemic in India. Results in Physics [online]. 30 [cit. 2021-10-20]. ISSN 22113797. Available at: doi:10.1016/j.rinp.2021.104630

Březinová, M., \& Průšová, J. (2014). SMALL AND MEDIUM-SIZED ENTEPRISES IN TERMS OF THEIR GOALS. In: ECONOMIC AND SOCIAL DEVELOPMENT: 5TH INTERNATIONAL SCIENTIFIC CONFERENCE BOOK OF PROCEEDINGS. Belgrade, SERBIA: Megatrend Univ, Varazdin Dev \& Entrepreneurship Agcy, p. 529-535.

Březinová, M., \& Vrchota, J. (2015). Communication of SMEs in the region of South Bohemia. In: 18th International Colloquium on Regional sciences. Conference Proceedings [online]. Brno: Masarykova univerzita, p. 136-142 [cit. 2021-12-14]. ISBN 978-80-210-7861-1. Available at: doi:10.5817/CZ.MUNI.P210-7861-2015-17

Chamizo, S., Rodríguz-Caballero, E., Sánchez-Canete, E. P., Domingo, F., \& Cantón, Y. (2022). Temporal dynamics of dryland soil CO2 efflux using high-frequency measurements: Patterns and dominant drivers 
among biocrust types, vegetation and bare soil. Geoderma [online]. 405 [cit. 2021-10-20]. ISSN 00167061. Available at: doi:10.1016/j.geoderma.2021.115404

Dhini, A., Surjandari, I., Riefqi, M., \& Puspasari, M. A. (2015). Forecasting Analysis of Consumer Goods Demand using Neural Networks and ARIMA. International Journal of Technology [online]. 2015, 6(5), 872-880 [cit. 2021-10-21]. ISSN 2087-2100. Available at: doi:10.14716/ijtech.v6i5.1882

Dias, R., Teixeira, N., Machová, V., Pardal, P., Horák, J., \& Vochozka, M. (2020). Random walks and market efficiency tests: evidence on US, Chinese and European capital markets within the context of the global Covid-19 pandemic. Oeconomia Copernicana [online]. 2020, 11(4), 585-608 [cit. 2021-12-14]. ISSN 2353-1827. Available at: doi:10.24136/oc.2020.024

Ghosh, I., Sanyal, M. K., \& Jana, R. K. (2020). An Ensemble of Ensembles Framework for Predictive Analytics of Commodity Market. In: 2020 4th International Conference on Computational Intelligence and Networks (CINE) [online]. IEEE, p. 1-6 [cit. 2021-10-6]. ISBN 978-1-7281-5688-0. Available at: doi:10.1109/CINE48825.2020.234398

Groda, B. \& Vrbka, J. (2017). Prediction of stock price developments using the Box-Jenkins method. In Váchal, Jan; Vochozka, Marek; Horák, Jakub. SHS Web of Conferences - Innovative Economic Symposium 2017: Strategic Partnership in International Trade. 1. vyd. Les Ulis, France: EDP Sciences, 9 s. ISBN 978-2-75989028-6. doi:10.1051/shsconf/20173901007.

Horák, J., \& Krulický, T. (2019). Comparison of exponential time series alignment and time series alignment using artificial neural networks by example of prediction of future development of stock prices of a specific company. SHS Web of Conferences [online]. 61 [cit. 2021-10-21]. ISSN 2261-2424. Available at: doi:10.1051/shsconf/20196101006

JI, Shenjia, Hongyan YU, Yinan GUO a Zongrun ZHANG. Research on sales forecasting based on ARIMA and BP neural network combined model. In: Proceedings of the 2016 International Conference on Intelligent Information Processing - ICIIP ' 16 [online]. New York, New York, USA: ACM Press, 2016, 2016, s. 1-6 [cit. 2021-10-22]. ISBN 9781450347990. Available at: doi:10.1145/3028842.3028883

Karlsson, M. \& Sjovaag, H. (2015). Content Analysis and Online News. Digital Journalism [online]. 4(1), 177192 [cit. 2021-10-22]. ISSN 2167-0811. Available at: doi:10.1080/21670811.2015.1096619

Kruml, L. \& Novotný J. (2016).. THE INVESTMENT POTENTIAL OF SILVER. Hradec Economics Days. 727 733.

Kurzy.cz [online]. [cit. 2021-11-13]. Available at: https://www.kurzy.cz/komodity/stribro-graf-vyvoje-ceny/

Lacy, S., Watson, B. R., Riffe, D. \& Lovejoy, J. (2015). Issues and Best Practices in Content Analysis. Journalism \& Mass Communication Quarterly [online]. 92(4), 791-811 [cit. 2021-10-21]. ISSN 1077-6990. Available at: doi:10.1177/1077699015607338

LIU, Zhenyu, Zhengtong ZHU, Jing GAO a Cheng XU. Forecast Methods for Time Series Data: A Survey. IEEE Access [online]. 2021, 9, 91896-91912 [cit. 2021-10-22]. ISSN 2169-3536. Available at: doi:10.1109/ACCESS.2021.3091162

Lotfi, E. (2119). Sensitivity Analysis of Economic Variables using Neuro-Fuzzy Approach. Scientia Iranica [online]. 0-0 [cit. 2021-10-20]. ISSN 2345-3605. Available at: doi:10.24200/sci.2019.5488.1305

Machová, V., Vochozka, M. \& Horák, J. (2019). Analysis of business companies based on artificial neural networks. SHS Web of Conferences [online]. 2019, 61 [cit. 2021-12-14]. ISSN 2261-2424. Available at: doi:10.1051/shsconf/20196101013

Ma, A. H. N. (2017). Online destination image: Comparing national tourism organisation's and tourists' perspectives. Tourism Management [online]. 60, 280-297 [cit. 2021-10-21]. ISSN 02615177. Available at: doi:10.1016/j.tourman.2016.12.012

Markevičiute, J., Bernatavečeiene, J., Levulieno, R., Medveder, V., Treigys, P., \& Venskus, J. (2022). AttentionBased and Time Series Models for Short-Term Forecasting of COVID-19 Spread. Computers, Materials \& Continua [online]. 70(1), 695-714 [cit. 2021-10-20]. ISSN 1546-2226. Available at: doi: $10.32604 / \mathrm{cmc} .2022 .018735$

Nouri, Z. (2021). A Review of the Applications of Biochemicals Interference in Medical Imaging with the Synthesis of Contrast Nanoparticles and Marker Design (PROBE). Biointerface Research in Applied Chemistry [online]. 12(2), 2251-2261 [cit. 2021-10-20]. ISSN 2069-5837. Available at: doi:10.33263/BRIAC122.22512261

Pezzuto, A., Losasso, C., Mancin, M., et al. (2015). Food safety concerns deriving from the use of silver based food packaging materials. Frontiers in Microbiology [online]. 2015, 6 [cit. 2021-10-7]. ISSN 1664-302X. Available at: doi:10.3389/fmicb.2015.01109

Phitthayanon, C., \& Rungreunganun, V. (2019). Material Cost Prediction for Jewelry Production Using Deep Learning Technique. Engineering Journal [online]. 23(6), 145-160 [cit. 2021-10-6]. ISSN 01258281. Available at: doi:10.4186/ej.2019.23.6.145 
Sadorsky, P. (2021). Predicting Gold and Silver Price Direction Using Tree-Based Classifiers. Journal of Risk and Financial Management [online]. 14(5) [cit. 2021-10-13]. ISSN 1911-8074. Available at: doi:10.3390/jrfm14050198

Saleh Ahmar, A., Kumar Singh, P., Van Thanh, N., Viet Tinh, N. \& Vo Minh Hieu. (2022) Prediction of BRIC Stock Price Using ARIMA, SutteARIMA, and Holt-Winters. Computers, Materials \& Continua [online]. 70(1), 523-534 [cit. 2021-10-20]. ISSN 1546-2226. Available at: doi:10.32604/cmc.2022.017068

Škapa, S., \& Vochozka, M. (2019). Waste energy recovery improves price competitiveness of artificial forage from rapeseed straw. Clean Techn Environ Policy 21, 1165-1171 [cit. 2021-12-15]. Available at: doi:10.1007/s10098-019-01697-x

Škapa, S., \& Vochozka, M. (2020). Towards Higher Moral and Economic Goals in Renewable Energy. Sci Eng Ethics 26, 1149-1158 [cit. 2021-12-15]. Available at: doi:10.1007/s11948-019-00109-Z

Slocum, T. A., \& Rolf, K. R. (2021). Features of Direct Instruction: Content Analysis. Behavior Analysis in Practice [online]. 14(3), 775-784 [cit. 2021-12-15]. ISSN 1998-1929. Available at: doi:10.1007/s40617021-00617-0

Stehel, V., \& Vochozka, M. (2016). Analiza ekonomske dodane vrijednosti u prijevozu. Naše more [online]. 63(3), 185-188 [cit. 2021-12-14]. ISSN 04696255. Available at: doi:10.17818/NM/2016/SI20

Suhermi, N., Suhartono, D., Prastyo, D. \& Ali, B. (2018). Roll motion prediction using a hybrid deep learning and ARIMA model. Procedia Computer Science [online]. 2018, 144, 251-258 [cit. 2021-10-22]. ISSN 18770509. Available at: doi:10.1016/j.procs.2018.10.526

Sutiksno, D. U., Ahmar, A. S., Kurniashih, N., Susanto, E. \& Leiwakabessy, A. (2018). Forecasting Historical Data of Bitcoin using ARIMA and $\alpha$-Sutte Indicator. Journal of Physics: Conference Series [online]. 1028 [cit. 2021-10-21]. ISSN 1742-6588. Available at: doi:10.1088/1742-6596/1028/1/012194

Sverdrup, H., Koca, D. \& Ragnarsdottir, K. V. (2014). Investigating the sustainability of the global silver supply, reserves, stocks in society and market price using different approaches. Resources, Conservation and Recycling [online]. 83, 121-140 [cit. 2021-10-13]. ISSN 09213449. Available at: doi:10.1016/j.resconrec.2013.12.008

Xu, J. (2021). Empire of silver: A new monetary history of China. Shanghai, China: Yale University Press. ISBN 978-030025004-6.

Vochozka, M. (2017). Neural network regression and linear regression in the estimate of the price of gold on the New York Stock Exchange. In Löster, Tomáš; Pavelka, Tomáš. The 11th International Days of Statistics and Economics Conference Proceedings. Praha, Česká republika: Libuše Macáková, Melandrium, p. 17801789, 10 s. ISBN 978-80-87990-12-4.

Vochozka, M., Horák, J., \& Krulický, T. (2020). Innovations in Management Forecast: Time Development of Stock Prices with Neural Networks. Marketing and Management of Innovations [online]. (2), $324-339$ [cit. 2021-10-21]. ISSN 22276718. Available at: doi:10.21272/mmi.2020.2-24

Vochozka, M., Horák, J., \& Šuleř, P. (2019). Equalizing Seasonal Time Series Using Artificial Neural Networks in Predicting the Euro-Yuan Exchange Rate. Journal of Risk and Financial Management [online]. 12(2) [cit. 2021-10-21]. ISSN 1911-8074. Available at: doi:10.3390/jrfm12020076

Vochozka, M., Rowland, Z., Šuleř, P., \& Maroušek, J. (2020). The Influence of the International Price of Oil on the Value of the EUR/USD Exchange Rate. Journal of Competitiveness, 12(2), 167-190. https://doi.org/10.7441/joc.2020.02.10

Vochozka, M., Vrbka, J., \& Šuleř, P. (2020). Bankruptcy or Success? The Effective Prediction of a Company's Financial Development Using LSTM. Sustainability [online]. 12(18) [cit. 2021-12-14]. ISSN 2071-1050. Available at: doi:10.3390/su12187529

Vrbka, J., Šuleř, P., Machová, V., \& Horák, J. (2019). Considering seasonal fluctuations in equalizing time series by means of artificial neural networks for predicting development of USA and People's Republic of China trade balance. Littera Scripta, 12(2), 161-175. ISSN 1805-9112.

Vrchota, J., \& Březinová, M. (2014). Characteristics of the labour market in the region of South Bohemia. In: 17th International Colloquium on Regional sciences. Conference Proceedings [online]. Brno: Masaryk University Press, 2014, p. 347-354 [cit. 2021-12-14]. ISBN 978-80-210-6840-7. Available at: doi:10.5817/CZ.MUNI.P210-6840-2014-43

Wang, S. \& Ji, Q. (2015). Video Affective Content Analysis: A Survey of State-of-the-Art Methods. IEEE Transactions on Affective Computing [online]. 6(4), 410-430 [cit. 2021-10-21]. ISSN 1949-3045. Available at: doi:10.1109/TAFFC.2015.2432791

Wojtyra, B., Kossowski, T. M., Březinová, M., Savov, R. \& Lančarič, D. (2020). Geography of craft breweries in Central Europe: Location factors and the spatial dependence effect. Applied Geography [online]. 124 [cit. 2021-12-14]. ISSN 01436228. Available at: doi:10.1016/j.apgeog.2020.102325 
Yan, C., Zhang, Y., Zhong, W., Zhang, C., \& Xin, B. (2022). A truncated SVD-based ARIMA model for multiple QoS prediction in mobile edge computing. Tsinghua Science and Technology [online]. 27(2), 315-324 [cit. 2021-10-20]. ISSN 1007-0214. Available at: doi:10.26599/TST.2021.9010040

Yaya, O. S., VO, X. V., \& Olayinka, H. A. (2021). Gold and silver prices, their stocks and market fear gauges: Testing fractional cointegration using a robust approach. Resources Policy [online]. 2021, 72 [cit. 202110-20]. ISSN 03014207. Available at: doi:10.1016/j.resourpol.2021.102045

Yin, Y. \& Shang, P. (2016). Forecasting traffic time series with multivariate predicting method. Applied Mathematics and Computation [online]. 291, 266-278 [cit. 2021-10-22]. ISSN 00963003. Available at: doi:10.1016/j.amc.2016.07.017

Yoo, J., So, H., Yang, M., \& Lee, K. (2019). Effect of chloride ion on synthesis of silver nanoparticle using retrieved silver chloride as a precursor from the electronic scrap. Applied Surface Science [online]. 475, 781-784 [cit. 2021-10-7]. ISSN 01694332. Available at: doi:10.1016/j.apsusc.2019.01.032 